\title{
Når hjertet løper løpsk
}

Atrieflimmer etter åpen hjertekirugi rammer omtrent halvparten av

pasientene. Kan sykepleiere jobbe mer kunnskapsbasert for tidlig å forutse og oppdage denne komplikasjonen?

\section{Forfattere}

Emma M. Midthun

Spesialsykepleier i kardiologisk sykepleie

Thoraxkirurgisk seksjon, Hjerteavdelingen, Haukeland universitetssjukehus

Ingelin L. Vatnaland

Lege i spesialisering

Thoraxkirurgisk seksjon, Hjerteavdelingen, Haukeland universitetssjukehus

Rune Haaverstad

Professor

Thoraxkirurgisk seksjon, Hjerteavdelingen, Haukeland universitetssjukehus

Trond R. Pettersen

Spesialsykepleier i kardiologisk sykepleie

Thoraxkirurgisk seksjon, Hjerteavdelingen, Haukeland universitetssjukehus og Institutt for sykepleiefag, Høgskulen på Vestlandet

Atrieflimmer Telemetri hjertekirurgi

Sykepleien 2019 107(75072)(e-75072)

DOI: https://doi.org/10.4220/Sykepleiens.2019.75072

\section{Hovedbudskap}

Postoperativt atrieflimmer er en hyppig forekommende komplikasjon som rammer omtrent halvparten av pasientene som har gjennomgått et åpent hjertekirurgisk inngrep. Det er derfor viktig at sykepleiere som jobber med pasienter i den postoperative fasen, er dyktige til å identifisere og oppdage potensielt livstruende arytmier og varsle om dette. Når atrieflimmer oppdages tidlig, kan pasienten få behandling før tilstanden forverres. 
Atrieflimmer (AF) er ansett som den hyppigst

forekommende komplikasjonen etter åpen

hjertekirurgi. Postoperativt atrieflimmer (POAF)

rammer 15-40 prosent av pasientene som

gjennomfører isolert koronar bypasskirurgi (Coronary

Artery Bypass Grafting, CABG), 37-50 prosent etter

klaffekirurgi og 60 prosent etter kombinerte inngrep

(1).

Atrieflimmer kjennetegnes ved uregelmessig

kontraksjon eller vibrering av atriene med

atriefrekvens på 350-650 slag/min (2, 3). Pasientens

puls avhenger av hvor mange og med hva slags

hastighet signalene fra atriene kommer igjennom til

ventriklene (Figur 1). Forekomsten av POAF ses i

sammenheng med tidligere sykdommer, kirurgiske

teknikker og om pasienten har flere sykdommer

samtidig (komorbiditet) $(4,5)$. Videre er POAF

assosiert med økte sykehuskostnader og

liggedøgn samt redusert langtidsoverlevelse (6).

Figur 1. Normal hjerterytme og atrieflimmer.

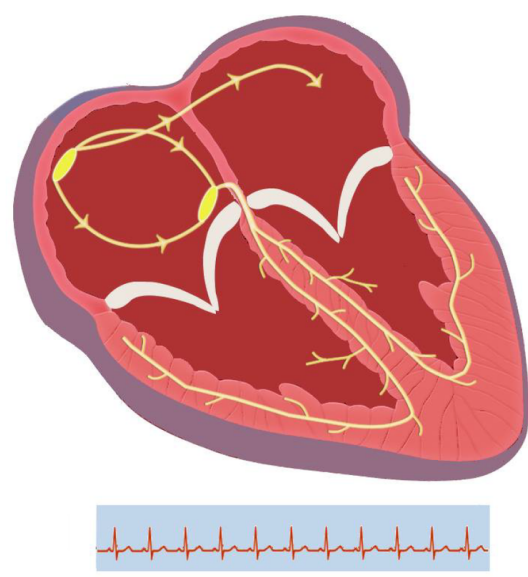

Normal hjerterytme

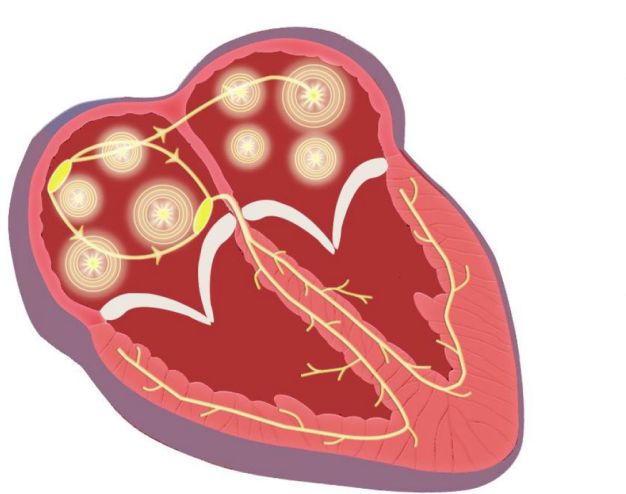

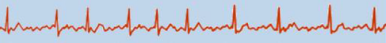

Atrieflimmer

Ved en thoraxkirurgisk sengepost har sykepleierne en viktig oppgave med å oppdage POAF tidlig hos pasienter som nylig har gjennomgått åpen hjertekirurgi. Sykepleiere er dyktige til å observere og oppdage signaler på kliniske komplikasjoner og kan dermed varsle lege tidlig slik at tiltak kan iverksettes. 
Å se risikofaktorer knyttet til POAF og i tillegg kunne observere hjerterytmen for å se etter endringer på telemetri eller ved pasientnær observasjon, gir sykepleierne mulighet til å jobbe forebyggende. Dette er ansett som erfaringsbasert kunnskap da sykepleiere med lang fartstid, bedre øvet klinisk blikk og med gode tilleggskunnskaper evner disse observasjonsteknikkene bedre. Hensikten med denne artikkelen er å undersøke hvordan sykepleiere kan jobbe kunnskapsbasert for å oppdage POAF tidlig hos en pasient som nylig har gjennomgått åpen hjertekirurgi.

\section{Postoperativt atrieflimmer}

Postoperativt atrieflimmer (POAF) oppstår oftest i løpet av de første dagene etter kirurgi, med høyest forekomst på andre og tredje postoperative dag $(1,7)$. Hos pasienter som ikke tidligere er diagnostisert med AF, er det rapportert at 15-30 prosent spontant konverterer tilbake til sinusrytme innen to timer, mens opptil 80 prosent konverterer tilbake innen det første døgnet (7). POAF reduserer den diastoliske fyllingen av ventriklene som ledsager redusert hjerteminuttvolum og fører også til økt oksygenbehov i myokardiet. Dette vil kunne resultere i hypotensjon og myokardiskemi. I tillegg kan mangelen på atriale kontraksjoner resultere i økt fyllingstrykk av venstre atrium, som vil gi økt trykk i lungekretsløpet og risiko for lungeødem. Dette gjelder spesielt for pasienter med moderat til alvorlig diastolisk dysfunksjon $(7,8)$.

POAF kan lett diagnostiseres med et 12-avlednings EKG eller telemetriovervåkning ved at det er bortfall av P-takker og uregelmessig QRS-kompleks (9).

De vanligste symptomene på AF er palpitasjoner, dyspné, svimmelhet, nærsynkope eller synkope. Symptomene forsterkes ved blodtrykksfall eller redusert hjerteminuttvolum. 


\section{$\equiv$ «Pasienter som opplever postoperativt atrieflimmer, beskriver det som hjertebank, ofte kombinert med utmattelse og tungpustethet.»}

Pasienter som opplever postoperativt atrieflimmer, beskriver det som hjertebank, ofte kombinert med utmattelse og tungpustethet (10). I mange tilfeller etterfølges disse symptomene av redsel og angst. POAF kan imidlertid også oppleves relativt symptomfritt, eller symptomene kan maskeres av andre problemer som kan oppstå etter hjertekirurgi.

\section{Risikofaktorer}

Årsakene til POAF er på langt nær fullstendig kartlagt (11), men anses som multifaktorielle og kan deles inn i preoperative faktorer og forhold som har direkte sammenheng med operasjonen og behandlingen pasienten gjennomgår.

\section{Preoperative risikofaktorer}

Preoperative risikofaktorer inkluderer grunnsykdommer og komorbiditeter, hvor økende alder og tidligere AF er ansett som de viktigste. Andre preoperative risikofaktorer inkluderer blant annet annen hjertesykdom, kols, diabetes mellitus og overvekt $(8,12)$.

\section{Alder}


Høy alder er den eneste systematisk beviste

risikofaktoren for å utvikle $\operatorname{POAF}(1,7,11,13)$. Etter

fylte 70 år øker risikoen for POAF med 75 prosent for hvert tiende år. Dette er assosiert med et mer komplekst sykdomsbilde hos den eldre pasienten og strukturelle forandringer både i atriene og i myokard for øvrig (5). Weiner og medarbeidere fant at økt venstre ventrikkelmasse er en sterk indikator for både atriale og ventrikulære takykardier (14). Videre viste Goette og medarbeidere at alder er relatert til atrial fibrose, og med større mengde atrial fibrose øker sjansen for POAF (15). Økt lengde på P-takken i EKG ( $\mathrm{P}>100 \mathrm{~ms}$ ) er også satt i sammenheng med endret fysiologi grunnet alder og dette er også assosiert med $ø k t$ risiko for $\operatorname{POAF}(7,11,15)$.

En studie av Gillespie og medarbeidere viste at antall liggedøgn økte med 4,6 dager for pasienter som utviklet POAF (16). I tillegg fant de at sykehuskostnadene økte med 14724 USD per pasient, noe som setter samfunnskostnadene per pasient i et økonomisk perspektiv. En annen studie, som inkluderte 19497 pasienter, viste at 30 dagers mortalitet ikke økte for pasienter med POAF, mens overlevelsen etter så vel ett, tre og et halvt, fem og sju år var signifikant lavere (6). Pasienter som i dag aksepteres for åpen hjertekirurgi, er ofte eldre, har et mer komplekst sykdomsbilde og er generelt mer hjertesyke enn tidligere (11).

Med betydelige ressurser satses det i dag på eldre pasienter med betydelig komorbiditet. Høy alder taler imot åpen hjertekirurgi, og både alder og forventet levetid bør belyses i sammenheng med levemuligheter og livskvalitet. Det kan derfor stilles spørsmål ved om eldre pasienter har økte liggedøgn på sykehus og kortere langtidsoverlevelse som et resultat av POAF eller på bakgrunn av alder og en mer avansert sykehistorie.

\section{Tidligere atrieflimmer}


Pasienter med tidligere diagnostisert AF rammes i

større grad av POAF. Strukturell hjertesykdom som forstørret venstre atrium, mitralklaffesykdom, hjertesvikt og hypertensjon, er kjente risikofaktorer for å utvikle både AF og POAF. Så mange som 70 prosent av pasienter med POAF har en forhistorie med AF (8). Dette viser at underliggende mekanismer for AF også spiller inn hos pasienter som utvikler AF etter gjennomgått hjertekirurgi $(11,17)$. AF er derfor en viktig risikofaktor for å utvikle POAF. Det er derfor viktig for sykepleiere som jobber med hjerteopererte, å vite at tidligere diagnostisert AF er en risikofaktor for å utvikle POAF. Dette kan gjøre noe med forventningene til at pasienten skal opprettholde sinusrytme postoperativt. Forebygging og behandling av høyfrekvent AF og informasjon til pasienten kan derfor bli vel så viktig som forebygging av POAF.

\section{Per- og postoperative risikofaktorer}

Det kirurgiske traumet ved en åpen hjerteoperasjon er i seg selv ansett som en risikofaktor for POAF (8). Av operasjonen som inkluderer effekten av hjerte-lungemaskinen, vil det komme en inflammatorisk respons som kan måles i form av C-reaktivt protein (CRP). Sammenhengen mellom økt CRP og forekomsten av POAF er ikke fullstendig forstått, men hyppigheten av POAF er høyest andre til tredje postoperative dag, parallelt med en stigning i CRP $(1,7,11,18,19)$. 
Infeksjonstilstander og feber er ikke utløsende årsaker til POAF, men CRP-stigning i forbindelse med infeksjoner kan vanskeliggjøre en konvertering tilbake til sinusrytme (19). Perikarditt er også ansett som en risikofaktor, da perikardektomi som må utføres ved enhver åpen hjerteoperasjon, gir en inflammatorisk respons $(1,11)$. Syre-, base- og væskebalansen påvirkes også i stor grad av operasjonen. Hypovolemi rammer mange pasienter i den postoperative fasen og kan komme av blodtap, feber og ødematøse endringer i kroppen. I verste fall kan dette føre til hypovolemisk sjokk. Videre kan ubalanse i elektrolytter føre til både atriale og ventrikulære arytmier (20) (figur 2).

Figur 2. Faktaboks om observasjon av risikofaktorer for postoperativ atrieflimmer

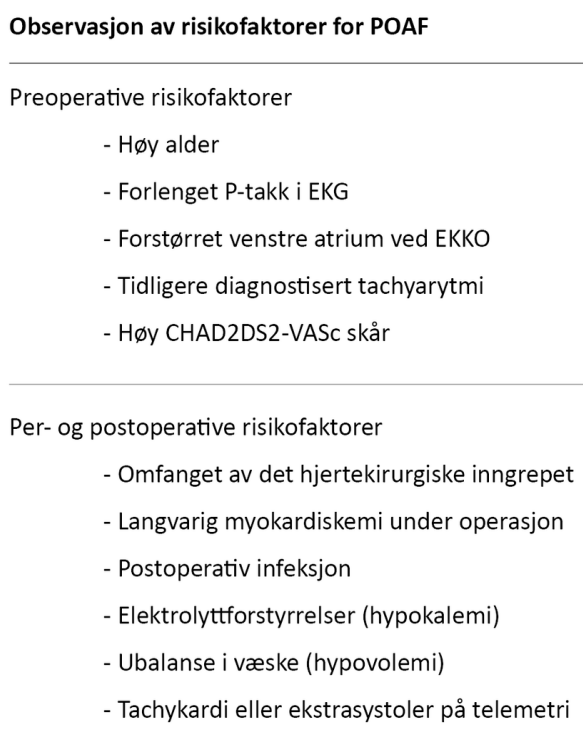

\section{Type hjerteoperasjon}

Forekomsten av POAF varierer mellom ulike typer hjerteoperasjoner og kirurgisk teknikk (1). Selv om bruk av hjerte-lunge-maskin bidrar til utvikling av POAF, har studier vist at typen kirurgisk inngrep og hyppigheten av POAF har en sammenheng. Pasienter som får utført isolert CABG, har lavere risiko for å utvikle POAF enn de som gjennomgår klaffekirurgi eller et kombinert inngrep $(1,7)$. 
En systemisk inflammatorisk respons oppstår under pasientens tid på hjerte-lunge-maskin på grunn av aktivering av komplementsystemet (11). Klaffekirurgi og kombinerte inngrep krever lengre tids ekstrakorporal sirkulasjon og lengre iskemitid for myokardiet og er derfor forbundet med økt risiko for POAF.

\section{Observasjon av hjerterytme}

Det er viktig at sykepleiere som jobber med pasienter i den postoperative fasen etter hjertekirurgi, er dyktige til å identifisere og oppdage potensielle livstruende arytmier i tillegg til å evaluere arytmiens kliniske påvirkning av systemsirkulasjonen (8). Grunnet det kirurgiske traumet, inflammatoriske effekter og øvrige risikofaktorer som disponerer for POAF, kan det oppstå en rekke signalforstyrrelser i hjertet. Sykepleiere skal kunne observere og identifisere disse signalforstyrrelsene, vurdere alvorlighetsgraden og varsle lege, slik at behandling eller forebyggende tiltak kan iverksettes.

\section{三 «Sykepleieren oppdager og varsler, mens legen iverksetter tiltak ut fra sykepleierens varsling.»}

Supraventrikulær ekstrasystole (SVES) er ekstraslag som har utspring fra nodalknuten eller atriene. SVES kan være indikasjon på atrialt stress og kan dermed anses som en forløper til AF (3). Ved hjelp av telemetrimonitorering kan SVES lett oppdages av en sykepleier, og rytmen kan tolkes ut fra hyppighet. Det er her sykepleierens forebyggende rolle kommer inn. Sykepleieren oppdager og varsler, mens legen iverksetter tiltak ut fra sykepleierens varsling. 
På lik linje med SVES kan også sinustakykardi (ST) og ventrikulær ekstrasystole anses som en forløper for AF (3). Sykepleieren tolker hyppigheten og lokalisasjonen av ekstrasystolen og varsler på lik linje som ved SVES. En ST kan både være et normalfenomen eller anses som patologisk. Hos en pasient som nylig har gjennomgått åpen hjertekirurgi, kan ST tolkes som en stressreaksjon eller iskemiskade i forbindelse med inngrepet. Uavhengig av årsak kan ST ses som en forløper til POAF, og her bør frekvensregulering iverksettes tidlig.

Å kunne oppdage endring i hjerterytme eller frekvens er viktig i det forebyggende arbeidet ved risiko for POAF. Det er derfor grunnleggende å vite hva som kreves for å få en god lesbar hjerterytme og å kunne se forskjell på artefakter og arytmi.

Preparering av huden der telemetrielektrodene skal plasseres, er viktig - dette området må være fritt for hår. I tillegg er «rubbing» av huden anbefalt av leverandøren av elektrodene. Telemetrielektrodene bør skiftes ut hvert døgn for å unngå hudreaksjoner eller dårlig kontakt. Elektrodene må være plassert riktig, og sykehusets retningslinjer for elektrodeplassering skal benyttes. I enkelte tilfeller må elektrodeplassering vike for bandasjer og andre anatomiske forandringer hos pasienten. Sykepleieren må vite alvorlighetsgraden av løse og feilplasserte telemetrielektroder, da dette kan vanskeliggjøre tolkningen av, eller endre utseendet på, hjerterytmen. Feiltolkning av artefakter og arytmi kan føre til uhensiktsmessig behandling eller feildiagnostisering (21) (figur 3).

Figur 3. Råd om hvordan telemetri kan optimaliseres

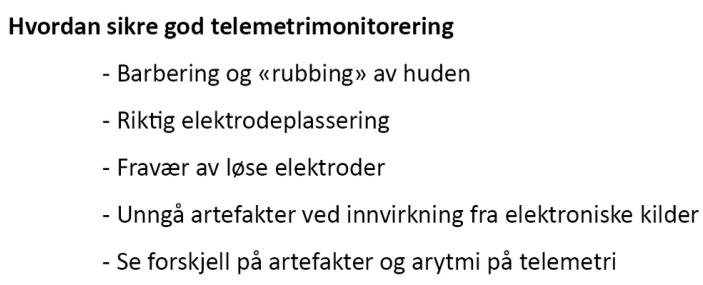




\section{Sykepleierens rolle}

Sykepleieren skal ha kunnskap om behandlingen pasienten får med tanke på å forebygge POAF. Bruk av betablokker som preventiv behandling er ifølge europeiske retningslinjer en klasse 1A-anbefaling og blir derfor gitt til alle pasienter som ikke har kontraindikasjoner mot disse medikamentene (22).

Statistisk sett utvikler de fleste pasientene ikke POAF. Disse pasientene kan imidlertid bli utsatt for profylaktisk behandling som potensielt har mange uønskede bivirkninger (17). Det er på bakgrunn av dette forsøkt å utarbeide flere verktøy for å skille ut høyrisikopasienter. Da man ser at risikoen for å utvikle AF og POAF er mye av det samme, er det forsøkt å ta i bruk CHA2DS2-VASc-skåringssystem for å definere høyrisikopasientene $(11,17)$ (figur 4).

Figur 4. CHA2DS2-VASC

\begin{tabular}{|c|c|c|}
\hline & Tilstand & Skår \\
\hline C & Hjertesvikt & 1 \\
\hline H & Hypertensjon & 1 \\
\hline$A_{2}$ & Alder > 75år & 2 \\
\hline D & Diabetes mellitus & 1 \\
\hline $\mathrm{S}_{2}$ & Tidligere slag, TIA eller trombeemboli & 2 \\
\hline V & Vaskulær sykdom & 1 \\
\hline A & Alder 65-75år & 1 \\
\hline Sc & Kvinnelig kjønn & 1 \\
\hline Skår & Risiko & Antikoagulasjon \\
\hline 0 & Lav & Ingen eller ASA \\
\hline 1 & Moderat & Oral antikoagulasjon eller ASA \\
\hline$>2$ & $\mathrm{H} \varnothing \mathrm{y}$ & Oral antikoagulasjon (Marevan) \\
\hline
\end{tabular}


Opprinnelig er dette skåringssystemet utviklet for å kalkulere risiko for hjerneslag hos pasienter med AF. Imidlertid hevder flere at CHA2DS2-VASc ikke bare sier noe om hvem som er predisponert for hjerneslag, men også hvem som er predisponert for å utvikle AF. Det kan derfor være grunn til å iverksette dette skåringssystemet hos pasienter som har økt risiko for å utvikle POAF $(23,24)$. Verdien av et slikt skåringssystem samt informasjon fra preoperativt EKG og ekkokardiografi kunne bidratt til et klarere skille mellom dem som bør få medikamentell profylakse i forhold til dem som har lavere risiko for POAF. Et slikt skåringssystem kan derfor hjelpe sykepleieren med å arbeide kunnskapsbasert i sin vurdering av pasienten.

\section{Kunnskapsbasert praksis}

Erfaringsbasert kunnskap anses som en hjørnestein i sykepleiekunnskap og er kunnskap som utvikles gjennom erfaringer og opplevelser. Dette hjelper sykepleiere i å utvikle klinisk blikk og ekspertise. Forskningsbasert kunnskap baserer seg på teorier og måler blant annet effekten av tiltak, forekomsten av en tilstand samt pasienters erfaring og opplevelser. A jobbe erfarings- eller forskningsbasert gir imidlertid ikke nok grunnlag til å ta gode beslutninger. Det er derfor ønskelig å utvikle en sykepleiepraksis der man bruker både forskning og erfaring (25).

\section{三 «Erfaringsbasert kunnskap anses som en hjørnestein i sykepleiekunnskap.»}

Det er sykepleierens ansvar som fagutøver å se hele pasienten, jobbe kunnskapsbasert og sette seg inn i pasientens tidligere sykehistorie. Videre må sykepleieren ha god observasjonsevne av pasientens kliniske tilstand, som også inkluderer hjerterytmen.

Først etter å ha mestret alle disse oppgavene kan sykepleieren jobbe kunnskapsbasert for tidlig å oppdage, varsle og iverksette tiltak mot POAF. 


\section{Oppsummering}

POAF rammer mellom 15-60 prosent av pasientene som har gjennomgått et åpent hjertekirurgisk inngrep. Forekomsten av POAF varierer med pasientens alder, tidligere sykdommer og omfanget av det hjertekirurgiske inngrepet. Alder og tidligere AF er de viktigste risikofaktorene for å utvikle POAF. Med god bakgrunnskunnskap samt evnen til å tolke hjerterytmer og til å jobbe kunnskapsbasert har sykepleiere en viktig oppgave med å oppdage signaler på risiko for POAF. Ved god observasjon og varsling om risiko eller nyoppstått POAF kan pasienten profittere på tidlig profylakse eller behandling før tilstanden forverres.

\section{Referanser}

1. Lee R. Atrial fibrillation and flutter after cardiac surgery. UpToDate; 2017. Tilgjengelig fra: https://www.uptodate.com/contents/atrial-fibrillationand-flutter-after-cardiac-surgery. (nedlastet 26.06.2017).

2. Thelle DS, Løchen M-L. Kaotiske hjerter. Atrieflimmer - en moderne epidemi. Oslo: Gyldendal Akademisk; 2010.

3. Ravnestad EM. Hjerter i takt og utakt. Et arbeidshefte i hjerterytmer. Bergen: Høgskolen i Bergen; 2011.

4. Auer J, Weber T, Berent R, Ng C-K, Lamm G, Eber B. Risk factors of postoperative atrial fibrillation after cardiac surgery. J Card Surg. 2005;20(5):425-31.

5. Pivatto Júnior F, Teixeira Filho GF, Sant'anna JRM, Py PM, Prates PR, Nesralla IA, et al. Advanced age and incidence of atrial fibrillation in the postoperative period of aortic valve replacement. Rev Bras Cir Cardiovasc. 2014;29(1):45-50. 
6. Saxena A, Dinh DT, Smith JA, Shardey GC, Reid CM, Newcomb AE. Usefulness of postoperative atrial fibrillation as an independent predictor for worse early and late outcomes after ilsolated coronary artery bypass grafting (multicenter Australian study of 19,497 patients). Am J Cardiol. 2012;109(2):219-25.

7. Peretto G, Durante A, Limite LR, Cianflone D. Postoperative arrhythmias after cardiac surgery: incidence, risk factors, and therapeutic management. Cardiol Res Pract. 2014;2014. DOI: $\underline{10.1155 / 2014 / 615987}$

8. Kaplow R. Postoperative dysrhythmias. I: Hardin SR, Kaplow R, red. Cardiac surgery essentials for critical care nursing. 2. utg. Burlingston: Jones \& Bertlett Learning; 2016. s. 307-26.

9. Frykman-Kull V, Insulander P, Rosenqvist M. Förmaksflimmer. I: Insulander P, Jensen-Urstad M, editors. Arytmier mekanismer, utredning och behandling. Lund: Studentlitteratur; 2015. s. 93-110.

10. Gjesdal K. Atrieflimmer og andre supraventrikulære arytmier. I: Forfang K, Istad H, Wiseth R, red. Kardiologi klinisk veileder. 2. utg. Oslo: Gyldendal Akademisk; 2015. s. 207-19.

11. Maesen B, Nijs J, Maessen J, Allessie M, Schotten U. Post-operative atrial fibrillation: a maze of mechanisms. EP Europace. 2012;14(2):159-74.

12. El-Chami MF, Kilgo PD, Elfstrom KM, Halkos M, Thourani V, Lattouf OM, et al. Prediction of new onset atrial fibrillation after cardiac revascularization surgery. Am J Cardiol. 2012;110(5):649-54.

13. Perrier S, Meyer N, Hoang Minh T, Announe

T, Bentz J, Billaud P, et al. Predictors of atrial fibrillation after coronary artery bypass grafting:

A bayesian analysis. Ann Thorac Surg. 2017;103(1):92-7. 
14. Weiner MM, Reich DL, Lin H-M, Krol M, Fischer GW. Increased left ventricular myocardial mass is associated with arrhythmias after cardiac surgery. J Cardiothorac Vasc Anesth. 2013;27(2):2927.

15. Goette A, Juenemann G, Peters B, Klein HU, Roessner A, Huth C, et al. Determinants and consequences of atrial fibrosis in patients undergoing open heart surgery. Cardiovasc Res. 2002;54(2):390-6.

16. Gillespie EL, White CM, Kluger J, Sahni J, Gallagher R, Coleman CI. A hospital perspective on the cost-effectiveness of $\beta$-Blockade for prophylaxis of atrial fibrillation after cardiothoracic surgery. Clin Ther. 2005;27(12):1963-9.

17. Mariscalco G, Biancari F, Zanobini M, Cottini M, Piffaretti G, Saccocci M, et al. Bedside tool for predicting the risk of postoperative atrial fibrillation after cardiac surgery: The POAF Score. J Am Heart Assoc: Cardiovascular and Cerebrovascular Disease. 2014;3(2):e000752.

18. Crea F, Marrow DA. C-reactive protein in cardiovascular disease [Internett]. UpToDate; 2017 Tilgjengelig fra: https://www.uptodate.com/contents/creactive-protein-in-cardiovascular-disease. (nedlastet 28.09.2017).

19. Ganz LI, Spragg D. Epidemiology of and risk factors for atrial fibrillation [Internett]. UpToDate; 2016 Tilgjengelig fra:

https://www.uptodate.com/contents/epidemiology-ofand-risk-factors-for-atrial-fibrillation. (nedlastet 28.08.2017).

20. Morelock V. Fluid and electrolyte imbalances following cardiac surgery. I: Hardin SR, Kaplow R, red. Cardiac surgery essentionals for critical cardiac nursing. 2. utg. Burlington: Jones \& Bartlett Learning; 2016. s. 353-82. 
21. Pettersen TR, Fålun N, Norekvål TM.

Improvement of in-hospital telemetry monitoring in coronary care units: An intervention study for achieving optimal electrode placement and attachment, hygiene and delivery of critical information to patients. Eur J Cardiovasc Nurs. 2013;13(6):515-23.

22. Windecker S, Kolh P, Alfonso F, Collet J-P, Cremer J, Falk V, et al. 2014 ESC/EACTS Guidelines on myocardial revascularization The Task Force on Myocardial Revascularization of the European Society of Cardiology (ESC) and the European Association for Cardio-Thoracic Surgery (EACTS). Developed with the special contribution of the European Association of Percutaneous Cardiovascular Interventions (EAPCI). Eur Heart J. 2014;35(37):2541-619.

23. Sareh S, Toppen W, Mukdad L, Satou N, Shemin R, Buch E, et al. CHADS2 score predicts atrial fibrillation following cardiac surgery. Journal of Surgical Research. 2014;190(2):407-12.

24. Kashani RG, Sareh S, Genovese B, Hershey C, Rezentes C, Shemin R, et al. Predicting postoperative atrial fibrillation using CHA2DS2-VASc scores. J Surg Res. 2015;198(2):267-72.

25. Nortvedt MW, Jamtvedt G, Graverholt B, Nordheim LV, Reinar LM. Jobb kunnskapsbasert! En arbeidsbok. 2. utg. Oslo: Akribe; 2012. 